\title{
A concise review of immunotherapy for glioblastoma
}

\author{
Omer Sager, Ferrat Dincoglan, Selcuk Demiral, Bora Uysal, Hakan Gamsiz, Bahar Dirican, \\ Murat Beyzadeoglu \\ Department of Radiation Oncology, University of Health Sciences, Gulhane Medical Faculty, Ankara 06018, Turkey.
}

Correspondence to: Assoc. Prof. Omer Sager, Department of Radiation Oncology, University of Health Sciences, Gulhane Medical Faculty, Gn.Tevfik Sağlam Cd. Etlik, Ankara 06018, Turkey. E-mail: omersager@gmail.com

How to cite this article: Sager O, Dincoglan F, Demiral S, Uysal B, Gamsiz H, Dirican B, Beyzadeoglu M. A concise review of immunotherapy for glioblastoma. Neuroimmuno/ Neuroinflammation 2018;5:25. http://dx.doi.org/10.20517/2347-8659.2018.12

Received: 26 Mar 2018 First Decision: 26 Apr 2018 Revised: 31 May 2018 Accepted: 5 Jun 2018 Published: 15 Jun 2018

Science Editor: Athanassios P. Kyritsis Copy Editor: Jun-Yao Li Production Editor: Cai-Hong Wang

\begin{abstract}
Glioblastoma (GB) is the most common and aggressive form of primary brain tumors in adults with a universally poor prognosis despite multimodal management including surgery, chemotherapy and radiation therapy. Among the novel therapeutic strategies, immunotherapy deserves particular attention with its potential to evoke biologic response and harness the host immune system. Considerable success achieved for other tumors has elicited great enthusiasm and prompted research on immunotherapy for GB. While the central nervous system has traditionally been thought of as an immune-privileged site, our understanding is being refined with emerging evidence. Several studies have been conducted and more are under way to establish the role of immunotherapy in management of GB. Immunotherapy of GB has yet resulted in mixed success with conflicting research findings, emphasizing the need for extensive study before its integration into routine clinical practice. Although there is a lot of room for improvement, immunotherapy for GB may be feasible and serve as a viable management strategy broadening and strengthening the therapeutic armamentarium to combat this deadly disease. Herein, we present a concise review of immunotherapy for GB.
\end{abstract}

Keywords: Glioblastoma, immunotherapy, glioma, vaccine, passive immunotherapy, active immunotherapy, cytokine therapy, central nervous system

\section{INTRODUCTION}

Glioblastoma (GB) constitutes the most common and aggressive form of primary brain tumors in adults $^{[1]}$. Management of newly diagnosed GB includes maximal tumor resection followed by adjuvant chemoradiotherapy. The landmark study by European Organisation for Research and Treatment of Cancer (EORTC)/National Cancer Institute of Canada Clinical Trials Group (NCIC-CTG) in 2005 has reported

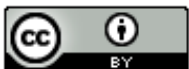

(C) The Author(s) 2018. Open Access This article is licensed under a Creative Commons Attribution 4.0 International License (https://creativecommons.org/licenses/by/4.0/), which permits unrestricted use, sharing, adaptation, distribution and reproduction in any medium or format, for any purpose, even commercially, as long as you give appropriate credit to the original author(s) and the source, provide a link to the Creative Commons license, and indicate if changes were made. 
significant median overall survival (OS) benefit with addition of temozolomide (TMZ) to conventionally fractionated radiation therapy (RT), making adjuvant chemoradiotherapy followed by adjuvant TMZ the standard of care for newly diagnosed GB patient ${ }^{[2]}$. However, disease recurrence is exceedingly common despite multimodal management. Repeat surgery, systemic agents and RT may be used in the recurrent setting as salvage therapeutic options, nevertheless, the clinical course is typically progressive with almost all patients ultimately succumbing to their disease $\mathrm{e}^{[3-5]}$.

Several treatment strategies are being explored to improve outcomes of patients with GB. Among these, immunotherapy deserves utmost attention with several studies assessing its role in GB management. Herein, we present a concise review of immunotherapy for GB.

\section{MAIN IMMUNOTHERAPY APPROACHES FOR GB}

Given the infiltrating nature of GB, diffuse microscopic disease may be typically present beyond the tumor bulk at initial presentation. Thus, a successful therapy should specifically address the infiltrative tumor stem cells surviving after implemented treatments such as surgery, chemotherapy and RT. Immunotherapy may conceptually take part in achieving this task, on the premise that it may facilitate combating with resistant GB cells through boosting of the host immune system. While the central nervous system (CNS) has traditionally been thought of as an immune-privileged site due to prevention of cellular and molecular diffusion by the blood-brain barrier and absence of lymphatic drainage, our understanding is being refined with emerging evidence ${ }^{[6-8]}$. The presence of a functional CNS lymphatic system has been reported recently and enhanced the focus on immunotherapy for brain tumors ${ }^{[9]}$.

Herein, we review main strategies for GB immunotherapy.

\section{Cytokine therapy}

The rationale of cytokine therapy is activation of the immune system through administration of immunomodulatory cytokines. Cytokines are secreted or membrane-bound proteins and potent immunomodulators with a critical role in immune system coordination ${ }^{[10-13]}$. Anti-tumor activities of cytokines have been reported in animal studies paving the way for consequent cytokine-based cancer treatment strategies. Among the multitude of cytokines including interleukins, interferons and hematopoietic growth factors, FDA approval is currently available for interferon alpha for adjuvant treatment of melanoma and for high-dose, bolus interleukin (IL)-2 for management of metastatic melanoma and renal cell cancer ${ }^{[13]}$.

An important issue in cytokine therapy is to achieve effective concentrations in the tumor without causing excessive toxicity. While local delivery by viral vectors has resulted in limited success for gliomas, intratumoral injection of IL-2 secreting allogeneic fibroblasts into GL261 tumors in mice has achieved increased survival ${ }^{[14-18]}$. Also, while IL-2 can induce over-differentiation of $\mathrm{T}$ cells and induce apoptosis of activated $\mathrm{T}$ cells, it may also activate $\mathrm{CD} 4+$ FoxP3 TREG regulatory cells, thereby inhibiting $\mathrm{T}$ cell activation and tumor killing activity. In this context, IL-7, IL-15, and IL-21 may also be used.

Liposomes and biopolymer microspheres are alternative routes utilized for intratumoral delivery of cytokines. Also, cytokines have been used for delivery of toxins in an effort to combat glioma cells with considerable success ${ }^{[19-21]}$.

Utility of cytokine immunotherapy in combination with other therapeutic modalities is being investigated to exploit the synergistic activity against GB cells ${ }^{[22]}$. Briefly, cytokine immunotherapy has achieved encouraging results despite the need for further supporting robust evidence. 


\section{Passive immunotherapy}

Serotherapy and adoptive immunotherapy are passive immunotherapy strategies. Passive immunotherapy is based on delivering the patient immune cells or antibodies with the capability of targeting the tumor cells ${ }^{[23]}$. Unlike active immunotherapy in which the patient's immune system is boosted, passive immunotherapy doesn't include activation of host immunity. Infusion of LAK cells into the tumor bed was an initial attempt of passive immunotherapy in the earlier years ${ }^{[24,25]}$. Cytotoxic $\mathrm{T}$ lymphocytes (CTLs) were also studied for adoptive immune response ${ }^{[26]}$.

The use of monoclonal antibodies as a passive immunotherapy approach may result in killing of tumor cells through different mechanisms ${ }^{[27]}$. Sparing of normal brain tissue without tumor may be achieved if the antigen targeted by the monoclonal antibody is specifically expressed by the tumor only. Vascular endothelial growth factor (VEGF) is highly expressed in GB and targeted for therapeutic exploitation with bevacizumab (BEV). As a recombinant humanized monoclonal antibody, BEV is bound to VEGF-A and exerts antitumor effect. An improvement in progression free survival and maintenance in quality-of-life and performance status has been reported with addition of BEV to RT and temozolomide ${ }^{[28]}$.

Another potential target in GB is the epidermal growth factor receptor (EGFR) ${ }^{[29]}$. EGFR gene mutation typically in EGFR variant III (EGFRvIII) is very common in GB. In this context, the use of anti-EGFRvIII antibodies in combined modality GB management is an area of active investigation.

\section{Adoptive T-cell immunotherapy}

Adoptive T-cell therapy offers an alternative immunotherapeutic approach. In this treatment, tumor-specific autologous T-cells undergo in vitro amplification and are consequently infused to the same individual for therapeutic exploitation. Advances in genetic engineering has paved the way for adoptive T-cell immunotherapy through generation of high avidity tumor-specific $\mathrm{T}$-cells ${ }^{[30]}$. Chimeric antibody receptor (CAR)-based treatments and cytomegalovirus (CMV) adoptive T-cell immunotherapy have great potential for further therapeutic exploitation ${ }^{[31-35]}$.

A unique advantage of adoptive T-cell immunotherapy is the capability of expanding substantial amounts of tumor infiltrating T lymphocytes (TILs) in vitro without immunosuppressive environments seen in vivo ${ }^{[36]}$.

Adverse effects of adoptive T-cell immunotherapy may include cytokine release syndrome (CRS) and tumor lysis syndrome (TLS) which underscore the importance of early detection of these syndromes through vigilant monitoring $^{[37,38]}$. CRS and neurotoxicity may be triggered by the inflammatory molecule IL-1, and adding ANAKINRA, an inhibitor of IL-1, to the treatment regimen can block the molecule. Also, inserting the IL-1 inhibitor gene directly into CAR-T cells may prevent CRS.

\section{Active immunotherapy (peptide vaccines, dendritic cell vaccines, heat shock protein vaccines)}

Active immunotherapy is based on the premise that vaccination against tumor antigen stimulates an adaptive immune response against tumor cells. Target antigens include tumor-specific antigens (TSAs) expressed solely by the tumor and tumor-associated antigens (TAAs) expressed by both tumor cells and normal cells. While TSAs have a greater potential to evoke a more potent and specific immune response compared to TAAs, they are exceedingly rare. EGFRvIII, IDH-1/2 mutations (e.g., R132H), and CMV proteins are known TSAs expressed in GB and IL-13Ra2, HER-2, gp100, survivin, WT1, TRP2, EphA2, SOX2, SOX11, MAGE-A1, MAGE-A3, AIM2, SART1, and tenascin are TAAs expressed in $\mathrm{GB}^{[10]}$.

Heterogeneity of GBs warrants the demand for individualized, patient-specific and non-toxic immunotherapies. Attracted by the success of vaccination against hormone-resistant metastatic prostate cancer, researchers have focused on developing vaccines against $\mathrm{GB}^{[39]}$. Herein, we review peptide vaccines, dendritic cell (DC) vaccines, and heat shock protein (HSP) vaccines. 


\section{Peptide vaccines}

This strategy is a targeted approach including the direct administration of a selected protein or peptide antigen frequently used with an adjuvant such as keyhole limpet hemocyanin (KLH) to enhance the immunogenicity ${ }^{[10,40,41]}$.

In the context of peptide vaccines, most extensive study has focused on targeting of EGFRvIII ${ }^{[42-44]}$. EGFRvIII is a TSA which is solely expressed by GB cells and not expressed by normal tissues ${ }^{[45]}$. This kind of targeting single tumor specific antigens has the advantage of theoretically eliminating normal tissue toxicity. The mutant form of the EGFR gene containing an in-frame deletion of exons 2-7 is found in approximately $20 \%-30 \%$ of patients with GB and causes tumor cell proliferation ${ }^{[46-49]}$.

In the recent phase II randomized ReACT study assessing association of rindopepimut and BEV in EGFRvIIIpositive relapsed GB patients reported the benefit of rindopepimut treatment with regard to multiple endpoints including the 2-year OS and PFS rates, and the authors concluded that rindopepimut administered with BEV induced a potent EGFRvIII-specific immune response leading to tumor regression and prolonged survival of recurrent GB patient ${ }^{[50]}$. Another phase II multicenter study of EGFRvIII peptide vaccination in newly diagnosed GB patients, Sampson et al.$^{[45]}$ reported significantly improved OS in vaccinated patients. A notable finding in this study was the loss of EGFRvIII antigen in most patients relapsing after vaccination, indicating a critical role for vaccine-induced immune response in tumor eradication. They concluded that a randomized phase III trial was needed to establish the role of EGFRvIII-targeted vaccination for management of GB patients ${ }^{[45]}$.

However, randomized phase III trial of rindopepimut for newly diagnosed EGFRvIII-positive GB patients failed to show an OS benefit in preplanned interim analysis, leading to early closure of the study ${ }^{[51]}$.

Overall, studies of Rindopepimut have demonstrated encouraging results worth further testing ${ }^{[2-54]}$. Nevertheless, GB TSAs with higher expression levels may achieve improved treatment results.

Other than EGFR related peptides, personalized peptide vaccination has been another area of investigation, resulting in encouraging therapeutic outcomes ${ }^{[5,56]}$. IDH-1 $\mathrm{R} 132 \mathrm{H}$ mutation is a newer appealing TSA with a typically lower prevalence in primary GB compared to secondary GB and is being currently tested in clinical studies $^{[5]]}$.

\section{DC vaccines}

DCs are efficacious antigen-presenting cells (APCs) capable of vigorously activating the T-cells to attain a durable immune response through slow processing of antigens ${ }^{[8-61]}$. These professional APCs have been judiciously utilized for GB management since they are appealing candidates for therapeutic exploitation. DCs can be categorized into myeloid DCs (mDCs) and plasmacytoid DCs (pDCs) ${ }^{[62,63]}$. In the study by Dey et al..$^{[63]}$, mice vaccinated with $\mathrm{mDCs}$ generated an improved antitumor $\mathrm{T}$ cell response compared to $\mathrm{pDC}$ vaccinated mice. The use of DC-based vaccines achieved impressive results for newly diagnosed GB patients ${ }^{[61]}$.

In the study by Prins et al. ${ }^{[64]}$, safety, feasibility, and immune responses were comparatively assessed for GB patients treated using DC pulsed with autologous tumor lysate or with synthetic glioma-associated antigens. The study revealed that DCs pulsed with autologous tumor lysates achieved improved anti-tumor immune response compared to DCs pulsed with synthetic glioma-associated antigens ${ }^{[64]}$. Nevertheless, DC vaccines may yet be skeptical in human clinical trials notwithstanding the promising results in animal models.

A recent study by Mitchell et al.$^{[65]}$ revealed that the efficacy of DC vaccination could be enhanced through pre-conditioning of the vaccination site with a recall antigen such as tetanus/diphtheria toxoid. 
Approaches for modulation of DC migration may prove to be a viable treatment option, however, modification of autologous DCs is a difficult task with a high cost and workload.

Another appealing immunotherapy approach includes targeting of the glioma stem cells (GSCs) which are considered to take part in treatment resistance ${ }^{[30,66]}$. A survival benefit has been achieved in rodent GB models by use of GSC-antigens loaded DC vaccination ${ }^{[30,67,68]}$.

\section{Heat shock protein vaccines}

Targeting of a single TSA or TAA with vaccines limit the potential antitumoral effect to the subgroup of GB patients expressing those TSAs and TAAs. Single-antigen vaccines also suffer from the heterogeneity of the GB cells expressing the antigen which may lead to their diminished activity and usefulness. In this context, an alternative strategy has been developed including vaccination with a heat shock protein (HSP) peptide complex in order to achieve targeting of multiple antigens ${ }^{[69]}$. The concentrations of HSPs may reach high levels in the presence of protein misfolding, unfolding, or aggregation and under stress-inducing environments as in $\mathrm{GB}^{[69-72]}$.

The use of HSP-peptide complex in management of recurrent GB patients has been tolerated well and conferred an improvement of survival through enhanced immune respons $\mathrm{e}^{[73]}$.

In a study by Crane et al. ${ }^{[74]}$, the use of peptides bound to a $96 \mathrm{kD}$ chaperone protein (HSP-96) for immunization of recurrent GB patients resulted in a median survival of 47 weeks after surgery and vaccination, indicating the efficacy of this approach. Another phase II trial by Bloch et al. ${ }^{[75]}$ reported the safety of HSPPC-96 vaccine in 41 recurrent GB patients and emphasized the need for vigilance for pretreatment lymphopenia as a factor impacting outcomes of immunotherapy.

The utility of another glioma-associated antigen HSP47 was suggested to induce CTL responses with the potential of therapeutic exploitation for GB patients ${ }^{[6,77]}$.

\section{Immune checkpoint therapy}

Immune checpoint inhibitors are immunomodulatory therapeutics with the capability of blocking inhibitory molecules and their receptors on effector immune cells with a resultant $\mathrm{T}$-cell response against various cancers ${ }^{[7]}$. Immune checkpoint therapy offers a viable immunotherapy strategy targeting the regulatory pathways in $\mathrm{T}$ cells to evoke an immune response against the tumor ${ }^{[79]}$. Boosting of the antitumor immunity by immune checkpoint inhibitors mediating the T-cell response has been an appealing strategy for therapeutic exploitation ${ }^{[80,81]}$.

Among the multitude of immune checkpoint molecules under current investigation and development for GB, cytotoxic T-lymphocyte-associated protein 4 (CTLA-4) and programmed death 1 (PD-1) are the most popular given the favorable outcomes achieved for other tumors through their inhibition, leading to FDA approval ${ }^{[82-86]}$. Studies have suggested the ability of these immune checkpoint inhibitors to overcome the blood-brain barrier for activity within the $\mathrm{CNS}^{[87-90]}$.

In the context of GB, their inhibition showed promise in preclinical trials ${ }^{[91-95]}$.

Although the first phase III study of PD pathway inhibition, the Checkmate 143 trial failed to meet its primary endpoint, several studies have focused on immune checkpoint inhibition for GB patients ${ }^{[96-98]}$.

As well as the enthusiasm for therapeutic exploitation of immune checkpoint blockade, there have also been important concerns about immune-related toxicity profile of immune checkpoint inhibitors, partly due to 
increased amount of proinflammatory cytokines along with aberrant infiltration of stimulated $\mathrm{T}$ cells into normal tissues ${ }^{[99,100]}$. Nevertheless, there is a lot of room for further improvement and immune checkpoint blockade may serve as a viable immunotherapeutic strategy for patients with GB.

\section{FUTURE DIRECTIONS}

Immunotherapy for GB is being thoroughly investigated in a plethora of studies to establish the safety and efficacy for therapeutic exploitation. Results of critical studies are eagerly awaited before decision making for integration of immunotherapy into clinical practice of GB management. A few points to be considered for GB immunotherapy are as follows:

-Further investigation and understanding of the immune system evasion mechanisms may assist in improved therapeutic exploitation of personalized immunotherapeutic strategies for GB patients. Focusing on molecular subtypes of GB and identification of molecular factors affecting the interplay between the tumor and immune system may be critical for developing personalized treatments for patients suffering from this deadly disease.

-Measurement of immune response may be further optimized through the introduction of standardized and validated assays, which play a central role in therapeutic decision making for a given immunotherapeutic. -Given the grim prognosis of GB patients, current standard management may be judiciously supported by boosting of antitumor response with immunotherapy. In this context, achieving an improved therapeutic ratio for GB patients may warrant the utilization of combination therapies with incorporation of immunotherapeutic approaches to exploit the advantage of synergistic antitumor activity of multiple treatment modalities.

Clearly, well-designed clinical trials are needed to assess efficacy and safety of combined modality GB management using immunotherapeutic agents. Improved understanding of the interactions between chemotherapy, radiotherapy and immunotherapeutic strategies will shed light on further research for optimization of more potent treatment of GB patients.

\section{CONCLUSION}

Recent years have witnessed unprecedented advances and breakthroughs in basic and translational cancer research, leading to significant improvements in therapeutic outcomes for several tumors. Utilization of immunotherapeutic strategies proved to be efficacious against several cancers, leading to their thorough investigation for management of GB patients. Immunotherapy of GB has yet resulted in mixed success with conflicting research findings, emphasizing the need for extensive study before its integration into routine clinical practice. Although there is a lot of room for improvement, immunotherapy for GB may be feasible and serve as a viable management strategy broadening and strengthening the therapeutic armamentarium to combat this deadly disease.

\section{DECLARATIONS}

\section{Authors' contributions}

Concept and design of study: Sager O, Dincoglan F, Dirican B, Beyzadeoglu M

Drafting the article: all authors

Revising the aticle critically for important intellectual content: Sager O, Dirican B, Beyzadeoglu M

Final approval of the version to be published: all authors

\section{Availability of data and materials}

Not applicable. 


\section{Financial support and sponsorship}

None.

\section{Conflicts of interest}

All authors declared that there are no conflicts of interest.

\section{Ethical approval and consent to participate}

Not applicable.

\section{Consent for publication}

Not applicable.

\section{Copyright}

(C) The Author(s) 2018.

\section{REFERENCES}

1. Paolillo M, Boselli C, Schinelli S. Glioblastoma under siege: an overview of current therapeutic strategies. Brain Sci 2018;8:E15.

2. Stupp R, Mason WP, van den Bent MJ, Weller M, Fisher B, Taphoorn MJ, Belanger K, Brandes AA, Marosi C, Bogdahn U, Curschmann J, Janzer RC, Ludwin SK, Gorlia T, Allgeier A, Lacombe D, Cairncross JG, Eisenhauer E, Mirimanoff RO; European Organisation for Research and Treatment of Cancer Brain Tumor and Radiotherapy Groups; National Cancer Institute of Canada Clinical Trials Group. Radiotherapy plus concomitant and adjuvant temozolomide for glioblastoma. N Engl J Med 2005;352:987-96.

3. Dincoglan F, Sager O, Demiral S, Uysal B, Gamsiz H, Dirican B, Beyzadeoglu M. Radiosurgery for recurrent glioblastoma: a review article. Neurol Disord Therap 2017;1:1-5.

4. Dincoglan F, Beyzadeoglu M, Sager O, Demiral S, Gamsiz H, Uysal B, Ebruli C, Akin M, Oysul K, Sirin S, Dirican B. Management of patients with recurrent glioblastoma using hypofractionated stereotactic radiotherapy. Tumori 2015;101:179-84.

5. Sirin S, Oysul K, Surenkok S, Sager O, Dincoglan F, Dirican B, Beyzadeoglu M. Linear accelerator-based stereotactic radiosurgery in recurrent glioblastoma: a single center experience. Vojnosanit Pregl 2011;68:961-6.

6. Heimberger AB, Sampson JH. Immunotherapy coming of age: what will it take to make it standard of care for glioblastoma? Neuro Oncol 2011;13:3-13.

7. Carson MJ, Doose JM, Melchior B, Schmid CD, Ploix CC. CNS immune privilege: hiding in plain sight. Immunol Rev 2006;213:48-65.

8. Sehgal A, Berger MS. Basic concepts of immunology and neuroimmunology. Neurosurg Focus 2000;9:e1.

9. Louveau A, Smirnov I, Keyes TJ, Eccles JD, Rouhani SJ, Peske JD, Derecki NC, Castle D, Mandell JW, Lee KS, Harris TH, Kipnis J. Structural and functional features of central nervous system lymphatic vessels. Nature 2015;523:337-41.

10. Farber SH, Elsamadicy AA, Atik AF, Suryadevara CM, Chongsathidkiet P, Fecci PE, Sampson JH. The safety of available immunotherapy for the treatment of glioblastoma. Expert Opin Drug Saf 2017;16:277-87.

11. Han SJ, Zygourakis C, Lim M, Parsa AT. Immunotherapy for glioma: promises and challenges. Neurosurg Clin N Am 2012;23:357-70.

12. Zhu VF, Yang J, Lebrun DG, Li M. Understanding the role of cytokines in glioblastoma multiforme pathogenesis. Cancer Lett 2012;316:139-50

13. Lee S, Margolin K. Cytokines in cancer immunotherapy. Cancers (Basel) 2011;3:3856-93.

14. Ren H, Boulikas T, Lundstrom K, Söling A, Warnke PC, Rainov NG. Immunogene therapy of recurrent glioblastoma multiforme with a liposomally encapsulated replication-incompetent Semliki forest virus vector carrying the human interleukin-12 gene--a phase I/II clinical protocol. J Neurooncol 2003;64:147-54

15. Glick RP, Lichtor T, Panchal R, Mahendra A, Cohen EP. Treatment with allogeneic interleukin-2 secreting fibroblasts protects against the development of malignant brain tumors. J Neurooncol 2003;64:139-46.

16. Ehtesham M, Samoto K, Kabos P, Acosta FL, Gutierrez MA, Black KL, Yu JS. Treatment of intracranial glioma with in situ interferongamma and tumor necrosis factor-alpha gene transfer. Cancer Gene Ther 2002;9:925-34.

17. Lichtor T, Glick RP, Tarlock K, Moffett S, Mouw E, Cohen EP. Application of interleukin-2-secreting syngeneic/allogeneic fibroblasts in the treatment of primary and metastatic brain tumors. Cancer Gene Ther 2002;9:464-9.

18. Lichtor T, Glick RP, Kim TS, Hand R, Cohen EP. Prolonged survival of mice with glioma injected intracerebrally with double cytokinesecreting cells. J Neurosurg 1995;83:1038-44.

19. Candolfi M, Kroeger KM, Xiong W, Liu C, Puntel M, Yagiz K, Muhammad AG, Mineharu Y, Foulad D, Wibowo M, Assi H, Baker GJ, Lowenstein PR, Castro MG. Targeted toxins for glioblastoma multiforme: pre-clinical studies and clinical implementation. Anticancer Agents Med Chem 2011;11:729-38.

20. Sampson JH, Akabani G, Archer GE, Bigner DD, Berger MS, Friedman AH, Friedman HS, Herndon JE 2nd, Kunwar S, Marcus S, McLendon RE, Paolino A, Penne K, Provenzale J, Quinn J, Reardon DA, Rich J, Stenzel T, Tourt-Uhlig S, Wikstrand C, Wong T, Williams R, Yuan F, Zalutsky MR, Pastan I. Progress report of a phase I study of the intracerebral microinfusion of a recombinant 
chimeric protein composed of transforming growth factor (TGF)-alpha and a mutated form of the pseudomonas exotoxin termed PE-38 (TP-38) for the treatment of malignant brain tumors. J Neurooncol 2003;65:27-35.

21. Heimbrook DC, Stirdivant SM, Ahern JD, Balishin NL, Patrick DR, Edwards GM, Defeo-Jones D, FitzGerald DJ, Pastan I, Oliff A. Transforming growth factor alpha-Pseudomonas exotoxin fusion protein prolongs survival of nude mice bearing tumor xenografts. Proc Natl Acad Sci U S A 1990;87:4697-701.

22. Haque A, Banik NL, Ray SK. Emerging role of combination of all-trans retinoic acid and interferon-gamma as chemoimmunotherapy in the management of human glioblastoma. Neurochem Res 2007;32:2203-9.

23. Thomas AA, Ernstoff MS, Fadul CE. Immunotherapy for the treatment of glioblastoma. Cancer J 2012;18:59-68.

24. Hayes RL, Koslow M, Hiesiger EM, Hymes KB, Hochster HS, Moore EJ, Pierz DM, Chen DK, Budzilovich GN, Ransohoff J. Improved long term survival after intracavitary interleukin-2 and lymphokine-activated killer cells for adults with recurrent malignant glioma. Cancer 1995;76:840-52.

25. Merchant RE, Grant AJ, Merchant LH, Young HF. Adoptive immunotherapy for recurrent glioblastoma multiforme using lymphokine activated killer cells and recombinant interleukin-2. Cancer 1988;62:665-71.

26. Kitahara T, Watanabe O, Yamaura A, Makino H, Watanabe T, Suzuki G, Okumura K. Establishment of interleukin 2 dependent cytotoxic $\mathrm{T}$ lymphocyte cell line specific for autologous brain tumor and its intracranial administration for therapy of the tumor. J Neurooncol 1987;4:329-36.

27. Chandramohan V, Mitchell DA, Johnson LA, Sampson JH, Bigner DD. Antibody, T-cell and dendritic cell immunotherapy for malignant brain tumors. Future Oncol 2013;9:977-90.

28. Chinot OL, Wick W, Mason W, Henriksson R, Saran F, Nishikawa R, Carpentier AF, Hoang-Xuan K, Kavan P, Cernea D, Brandes AA, Hilton M, Abrey L, Cloughesy T. Bevacizumab plus radiotherapy-temozolomide for newly diagnosed glioblastoma. N Engl J Med 2014;370:709-22.

29. Westphal M, Heese O, Steinbach JP, Schnell O, Schackert G, Mehdorn M, Schulz D, Simon M, Schlegel U, Senft C, Geletneky K, Braun C, Hartung JG, Reuter D, Metz MW, Bach F, Pietsch T. A randomised, open label phase III trial with nimotuzumab, an anti-epidermal growth factor receptor monoclonal antibody in the treatment of newly diagnosed adult glioblastoma. Eur J Cancer 2015;51:522-32.

30. Huang B, Zhang H, Gu L, Ye B, Jian Z, Stary C, Xiong X. Advances in immunotherapy for glioblastoma multiforme. J Immunol Res 2017;2017:3597613.

31. Reap EA, Suryadevara CM, Batich KA, Sanchez-Perez L, Archer GE, Schmittling RJ, Norberg PK, Herndon JE 2nd, Healy P, Congdon KL, Gedeon PC, Campbell OC, Swartz AM, Riccione KA, Yi JS, Hossain-Ibrahim MK, Saraswathula A, Nair SK, Dunn-Pirio AM, Broome TM, Weinhold KJ, Desjardins A, Vlahovic G, McLendon RE, Friedman AH, Friedman HS, Bigner DD, Fecci PE, Mitchell DA, Sampson JH. Dendritic cells enhance polyfunctionality of adoptively transferred T cells that target cytomegalovirus in glioblastoma. Cancer Res 2018;78:256-64.

32. Brown CE, Alizadeh D, Starr R, Weng L, Wagner JR, Naranjo A, Ostberg JR, Blanchard MS, Kilpatrick J, Simpson J, Kurien A, Priceman SJ, Wang X, Harshbarger TL, D’Apuzzo M, Ressler JA, Jensen MC, Barish ME, Chen M, Portnow J, Forman SJ, Badie B. Regression of glioblastoma after chimeric antigen receptor T-cell therapy. N Engl J Med 2016;375:2561-9.

33. Brown CE, Badie B, Barish ME, Weng L, Ostberg JR, Chang WC, Naranjo A, Starr R, Wagner J, Wright C, Zhai Y, Bading JR, Ressler JA, Portnow J, D’Apuzzo M, Forman SJ, Jensen MC. Bioactivity and safety of IL13R 2 2-redirected chimeric antigen receptor CD8+ T cells in patients with recurrent glioblastoma. Clin Cancer Res 2015;21:4062-72.

34. Schuessler A, Smith C, Beagley L, Boyle GM, Rehan S, Matthews K, Jones L, Crough T, Dasari V, Klein K, Smalley A, Alexander H, Walker DG, Khanna R. Autologous T-cell therapy for cytomegalovirus as a consolidative treatment for recurrent glioblastoma. Cancer Res 2014;74:3466-76.

35. Ohno M, Ohkuri T, Kosaka A, Tanahashi K, June CH, Natsume A, Okada H. Expression of miR-17-92 enhances anti-tumor activity of T-cells transduced with the anti-EGFRvIIIchimeric antigen receptor in mice bearing human GBM xenografts. J Immunother Cancer $2013 ; 1: 21$.

36. Rosenberg SA, Restifo NP. Adoptive cell transfer as personalized immunotherapy for human cancer. Science 2015;348:62-8.

37. Lee DW, Gardner R, Porter DL, Louis CU, Ahmed N, Jensen M, Grupp SA, Mackall CL. Current concepts in the diagnosis and management of cytokine release syndrome. Blood 2014;124:188-95.

38. Porter DL, Levine BL, Kalos M, Bagg A, June CH. Chimeric antigen receptor-modified T cells in chronic lymphoid leukemia. N Engl J Med 2011;365:725-33.

39. Kantoff PW, Higano CS, Shore ND, Berger ER, Small EJ, Penson DF, Redfern CH, Ferrari AC, Dreicer R, Sims RB, Xu Y, Frohlich MW, Schellhammer PF; IMPACT Study Investigators. Sipuleucel-T immunotherapy for castration-resistant prostate cancer. N Engl J Med 2010;363:411-22.

40. Neagu MR, Reardon DA. An update on the role of immunotherapy and vaccine strategies for primary brain tumors. Curr Treatment Options Oncol 2015;16:54.

41. Fecci PE, Heimberger AB, Sampson JH. Immunotherapy for primary brain tumors: no longer a matter of privilege. Clin Cancer Res 2014;20:5620-9.

42. Calinescu AA, Kamran N, Baker G, Mineharu Y, Lowenstein PR, Castro MG. Overview of current immunotherapeutic strategies for glioma. Immunotherapy 2015;7:1073-104.

43. Reardon DA, Freeman G, Wu C, Chiocca EA, Wucherpfennig KW, Wen PY, Fritsch EF, Curry WT Jr, Sampson JH, Dranoff G. Immunotherapy advances for glioblastoma. Neuro Oncol 2014;16:1441-58. 
44. Jackson CM, Lim M, Drake CG. Immunotherapy for brain cancer: recent progress and future promise. Clin Cancer Res 2014;20:3651-9.

45. Sampson JH, Heimberger AB, Archer GE, Aldape KD, Friedman AH, Friedman HS, Gilbert MR, Herndon JE 2nd, McLendon RE, Mitchell DA, Reardon DA, Sawaya R, Schmittling RJ, Shi W, Vredenburgh JJ, Bigner DD. Immunologic escape after prolonged progression-free survival with epidermal growth factor receptor variant III peptide vaccination in patients with newly diagnosed glioblastoma. J Clin Oncol 2010;28:4722-9.

46. Touat M, Idbaih A, Sanson M, Ligon KL. Glioblastoma targeted therapy: updated approaches from recent biological insights. Ann Oncol 2017;28:1457-72

47. Xu LW, Chow KK, Lim M, Li G. Current vaccine trials in glioblastoma: a review. J Immunol Res 2014;2014:796856.

48. Pelloski CE, Ballman KV, Furth AF, Zhang L, Lin E, Sulman EP, Bhat K, McDonald JM, Yung WK, Colman H, Woo SY, Heimberger AB, Suki D, Prados MD, Chang SM, Barker FG 2nd, Buckner JC, James CD, Aldape K. Epidermal growth factor receptor variant III status defines clinically distinct subtypes of glioblastoma. J Clin Oncol 2007;25:2288-94.

49. Heimberger AB, Suki D, Yang D, Shi W, Aldape K. The natural history of EGFR and EGFRvIII in glioblastoma patients. J Transl Med $2005 ; 3: 38$

50. Reardon DA, Desjardins A, Schuster J, Tran DD, Fink KL, Nabors LB, Li G, Bota DA, Lukas RV, Ashby LS, Duic JP, Mrugala MM, Werner A, Vitale L, He Y, Green J, Yellin MJ, Turner CD, Davis TA, Sampson JH. IMCT-08ReACT: long-term survival from a randomized phase II study of rindopepimut (CDX-110) plus bevacizumab in relapsed glioblastoma. Neuro Oncol 2015;17:v109.

51. Weller M, Butowski N, Tran DD, Recht LD, Lim M, Hirte H, Ashby L, Mechtler L, Goldlust SA, Iwamoto F, Drappatz J, O'Rourke DM, Wong M, Hamilton MG, Finocchiaro G, Perry J, Wick W, Green J, He Y, Turner CD, Yellin MJ, Keler T, Davis TA, Stupp R, Sampson JH; ACTIV trial investigators. Rindopepimut with temozolomide for patients with newly diagnosed, EGFRvIII-expressing glioblastoma (ACT IV): a randomised, double-blind, international phase 3 trial. Lancet Oncol 2017;18:1373-85.

52. Elsamadicy AA, Chongsathidkiet P, Desai R, Woroniecka K, Farber SH, Fecci PE, Sampson JH. Prospect of rindopepimut in the treatment of glioblastoma. Expert Opin Biol Ther 2017;17:507-13.

53. Paff M, Alexandru-Abrams D, Hsu FP, Bota DA. The evolution of the EGFRvIII (rindopepimut) immunotherapy for glioblastoma multiforme patients. Hum Vaccin Immunother 2014;10:3322-31.

54. Swartz AM, Li QJ, Sampson JH. Rindopepimut: a promising immunotherapeutic for the treatment of glioblastoma multiforme. Immunotherapy 2014;6:679-90.

55. Terasaki M, Shibui S, Narita Y, Fujimaki T, Aoki T, Kajiwara K, Sawamura Y, Kurisu K, Mineta T, Yamada A, Itoh K. Phase I trial of a personalized peptide vaccine for patients positive for human leukocyte antigen--A24 with recurrent or progressive glioblastoma multiforme. J Clin Oncol 2011;29:337-44.

56. Yajima N, Yamanaka R, Mine T, Tsuchiya N, Homma J, Sano M, Kuramoto T, Obata Y, Komatsu N, Arima Y, Yamada A, Shigemori M, Itoh K, Tanaka R. Immunologic evaluation of personalized peptide vaccination for patients with advanced malignant glioma. Clin Cancer Res 2005;11:5900-11.

57. Dimitrov L, Hong CS, Yang C, Zhuang Z, Heiss JD. New developments in the pathogenesis and therapeutic targeting of the IDH1 mutation in glioma. Int J Med Sci 2015;12:201-13.

58. Goyvaerts C, Breckpot K. Pros and cons of antigen-presenting cell targeted tumor vaccines. J Immunol Res 2015;2015:785634.

59. Bregy A, Wong TM, Shah AH, Goldberg JM, Komotar RJ. Active immunotherapy using dendritic cells in the treatment of glioblastoma multiforme. Cancer Treat Rev 2013;39:891-907.

60. Palucka K, Banchereau J. Cancer immunotherapy via dendritic cells. Nat Rev Cancer 2012;12:265-77.

61. Liau LM, Prins RM, Kiertscher SM, Odesa SK, Kremen TJ, Giovannone AJ, Lin JW, Chute DJ, Mischel PS, Cloughesy TF, Roth MD. Dendritic cell vaccination in glioblastoma patients induces systemic and intracranial T-cell responses modulated by the local central nervous system tumor microenvironment. Clin Cancer Res 2005;11:5515-25.

62. Alexiou GA, Kyritsis AP. Immunotherapeutic strategies for glioma treatment. Neuroimmunol Neuroinflammation 2016;3:51-6.

63. Dey M, Chang AL, Miska J, Wainwright DA, Ahmed AU, Balyasnikova IV, Pytel P, Han Y, Tobias A, Zhang L, Qiao J, Lesniak MS. Dendritic cell-based vaccines that utilize myeloid rather than plasmacytoid cells offer a superior survival advantage in malignant glioma. J Immunol 2015;195:367-76.

64. Prins RM, Wang X, Soto H, Young E, Lisiero DN, Fong B, Everson R, Yong WH, Lai A, Li G, Cloughesy TF, Liau LM. Comparison of glioma-associated antigen peptide-loaded versus autologous tumor lysate-loaded dendritic cell vaccination in malignant glioma patients. J Immunother 2013;36:152-7.

65. Mitchell DA, Batich KA, Gunn MD, Huang MN, Sanchez-Perez L, Nair SK, Congdon KL, Reap EA, Archer GE, Desjardins A, Friedman AH, Friedman HS, Herndon JE 2nd, Coan A, McLendon RE, Reardon DA, Vredenburgh JJ, Bigner DD, Sampson JH. Tetanus toxoid and CCL3 improve dendritic cell vaccines in mice and glioblastoma patients. Nature 2015;519:366-9.

66. Esparza R, Azad TD, Feroze AH, Mitra SS, Cheshier SH. Glioblastoma stem cells and stem cell-targeting immunotherapies. J Neurooncol 2015;123:449-57.

67. Xu Q, Liu G, Yuan X, Xu M, Wang H, Ji J, Konda B, Black KL, Yu JS. Antigen-specific T-cell response from dendritic cell vaccination using cancer stem-like cell-associated antigens. Stem Cells 2009;27:1734-40.

68. Pellegatta S, Poliani PL, Corno D, Menghi F, Ghielmetti F, Suarez-Merino B, Caldera V, Nava S, Ravanini M, Facchetti F, Bruzzone MG, Finocchiaro G. Neurospheres enriched in cancer stem-like cells are highly effective in eliciting a dendritic cell-mediated immune response against malignant gliomas. Cancer Res 2006;66:10247-52.

69. Ampie L, Choy W, Lamano JB, Fakurnejad S, Bloch O, Parsa AT. Heat shock protein vaccines against glioblastoma: from bench to bedside. J Neurooncol 2015;123:441-8. 
70. Christians ES, Zhou Q, Renard J, Benjamin IJ. Heat shock proteins in mammalian development. Semin Cell Dev Biol 2003;14:283-90.

71. Parsell DA, Lindquist S. The function of heat-shock proteins in stress tolerance: degradation and reactivation of damaged proteins. Annu Rev Genet 1993;27:437-96.

72. Strbo N, Garcia-Soto A, Schreiber TH, Podack ER. Secreted heat shock protein gp96-Ig: next-generation vaccines for cancer and infectious diseases. Immunol Res 2013;57:311-25.

73. See AP, Pradilla G, Yang I, Han S, Parsa AT, Lim M. Heat shock protein-peptide complex in the treatment of glioblastoma. Expert Rev Vaccines 2011;10:721-31.

74. Crane CA, Han SJ, Ahn B, Oehlke J, Kivett V, Fedoroff A, Butowski N, Chang SM, Clarke J, Berger MS, McDermott MW, Prados MD, Parsa AT. Individual patient-specific immunity against high-grade glioma after vaccination with autologous tumor derived peptides bound to the 96 KD chaperone protein. Clin Cancer Res 2013;19:205-14.

75. Bloch O, Crane CA, Fuks Y, Kaur R, Aghi MK, Berger MS, Butowski NA, Chang SM, Clarke JL, McDermott MW, Prados MD, Sloan AE, Bruce JN, Parsa AT. Heat-shock protein peptide complex-96 vaccination for recurrent glioblastoma: a phase II, single-arm trial. Neuro Oncol 2014;16:274-9.

76. Oh T, Sayegh ET, Fakurnejad S, Oyon D, Lamano JB, DiDomenico JD, Bloch O, Parsa AT. Vaccine therapies in malignant glioma. Curr Neurol Neurosci Rep 2015;15:508.

77. Wu ZB, Cai L, Qiu C, Zhang AL, Lin SJ, Yao Y, Xu J, Zhou LF. CTL responses to HSP47 associated with the prolonged survival of patients with glioblastomas. Neurology 2014;82:1261-5.

78. Polivka J Jr, Polivka J, Holubec L, Kubikova T, Priban V, Hes O, Pivovarcikova K, Treskova I. Advances in experimental targeted therapy and immunotherapy for patients with glioblastoma multiforme. Anticancer Res 2017;37:21-33.

79. Sharma P, Allison JP. The future of immune checkpoint therapy. Science 2015;348:56-61.

80. Topalian SL, Taube JM, Anders RA, Pardoll DM. Mechanism-driven biomarkers to guide immune checkpoint blockade in cancer therapy. Nat Rev Cancer 2016;16:275-87.

81. Pardoll DM. The blockade of immune checkpoints in cancer immunotherapy. Nat Rev Cancer 2012;12:252-64.

82. Carlino MS, Long GV. Ipilimumab combined with nivolumab: a standard of care for the treatment of advanced melanoma? Clin Cancer Res 2016;22:3992-8.

83. Larkin J, Chiarion-Sileni V, Gonzalez R, Grob JJ, Cowey CL, Lao CD, Schadendorf D, Dummer R, Smylie M, Rutkowski P, Ferrucci PF, Hill A, Wagstaff J, Carlino MS, Haanen JB, Maio M, Marquez-Rodas I, McArthur GA, Ascierto PA, Long GV, Callahan MK, Postow MA, Grossmann K, Sznol M, Dreno B, Bastholt L, Yang A, Rollin LM, Horak C, Hodi FS, Wolchok JD. Combined nivolumab and ipilimumab or monotherapy in untreated melanoma. N Engl J Med 2015;373:23-34.

84. Robert C, Schachter J, Long GV, Arance A, Grob JJ, Mortier L, Daud A, Carlino MS, McNeil C, Lotem M, Larkin J, Lorigan P, Neyns B, Blank CU, Hamid O, Mateus C, Shapira-Frommer R, Kosh M, Zhou H, Ibrahim N, Ebbinghaus S, Ribas A; KEYNOTE-006 investigators. Pembrolizumab versus ipilimumab in advanced melanoma. N Engl J Med 2015;372:2521-32.

85. Weber JS, D’Angelo SP, Minor D, Hodi FS, Gutzmer R, Neyns B, Hoeller C, Khushalani NI, Miller WH Jr, Lao CD, Linette GP, Thomas L, Lorigan P, Grossmann KF, Hassel JC, Maio M, Sznol M, Ascierto PA, Mohr P, Chmielowski B, Bryce A, Svane IM, Grob JJ, Krackhardt AM, Horak C, Lambert A, Yang AS, Larkin J. Nivolumab versus chemotherapy in patients with advanced melanoma who progressed after anti-CTLA-4 treatment (CheckMate 037): a randomised, controlled, open-label, phase 3 trial. Lancet Oncol 2015;16:375-84.

86. Hodi FS, O’Day SJ, McDermott DF, Weber RW, Sosman JA, Haanen JB, Gonzalez R, Robert C, Schadendorf D, Hassel JC, Akerley W, van den Eertwegh AJ, Lutzky J, Lorigan P, Vaubel JM, Linette GP, Hogg D, Ottensmeier CH, Lebbé C, Peschel C, Quirt I, Clark JI, Wolchok JD, Weber JS, Tian J, Yellin MJ, Nichol GM, Hoos A, Urba WJ. Improved survival with ipilimumab in patients with metastatic melanoma. N Engl J Med 2010;363:711-23.

87. Goldberg SB, Gettinger SN, Mahajan A, Chiang AC, Herbst RS, Sznol M, Tsiouris AJ, Cohen J, Vortmeyer A, Jilaveanu L, Yu J, Hegde U, Speaker S, Madura M, Ralabate A, Rivera A, Rowen E, Gerrish H, Yao X, Chiang V, Kluger HM. Pembrolizumab for patients with melanoma or non-small-cell lung cancer and untreated brain metastases: early analysis of a non-randomised, open-label, phase 2 trial. Lancet Oncol 2016;17:976-83.

88. Rosell R, Karachaliou N. Trends in immunotherapy for brain metastases. Lancet Oncol 2016;17:859-60.

89. Di Giacomo AM, Ascierto PA, Queirolo P, Pilla L, Ridolfi R, Santinami M, Testori A, Simeone E, Guidoboni M, Maurichi A, Orgiano L, Spadola G, Del Vecchio M, Danielli R, Calabrò L, Annesi D, Giannarelli D, Maccalli C, Fonsatti E, Parmiani G, Maio M. Threeyear follow-up of advanced melanoma patients who received ipilimumab plus fotemustine in the Italian Network for Tumor Biotherapy (NIBIT)-M1 phase II study. Ann Oncol 2015;26:798-803.

90. Margolin K, Ernstoff MS, Hamid O, Lawrence D, McDermott D, Puzanov I, Wolchok JD, Clark JI, Sznol M, Logan TF, Richards J, Michener T, Balogh A, Heller KN, Hodi FS. Ipilimumab in patients with melanoma and brain metastases: an open-label, phase 2 trial. Lancet Oncol 2012;13:459-65.

91. Reardon DA, Gokhale PC, Klein SR, Ligon KL, Rodig SJ, Ramkissoon SH, Jones KL, Conway AS, Liao X, Zhou J, Wen PY, Van Den Abbeele AD, Hodi FS, Qin L, Kohl NE, Sharpe AH, Dranoff G, Freeman GJ. Glioblastoma eradication following immune checkpoint blockade in an orthotopic, immunocompetent model. Cancer Immunol Res 2016;4:124-35.

92. Huang BY, Zhan YP, Zong WJ, Yu CJ, Li JF, Qu YM, Han S. The PD-1/B7-H1 pathway modulates the natural killer cells versus mouse glioma stem cells. PLoS One 2015;10:e0134715.

93. Wainwright DA, Chang AL, Dey M, Balyasnikova IV, Kim CK, Tobias A, Cheng Y, Kim JW, Qiao J, Zhang L, Han Y, Lesniak MS. Durable therapeutic efficacy utilizing combinatorial blockade against IDO, CTLA-4, and PD-L1 in mice with brain tumors. Clin Cancer 
Res 2014;20:5290-301.

94. Belcaid Z, Phallen JA, Zeng J, See AP, Mathios D, Gottschalk C, Nicholas S, Kellett M, Ruzevick J, Jackson C, Albesiano E, Durham NM, Ye X, Tran PT, Tyler B, Wong JW, Brem H, Pardoll DM, Drake CG, Lim M. Focal radiation therapy combined with 4-1BB activation and CTLA-4 blockade yields long-term survival and a protective antigen-specific memory response in a murine glioma model. PLoS One 2014;9:e101764.

95. Zeng J, See AP, Phallen J, Jackson CM, Belcaid Z, Ruzevick J, Durham N, Meyer C, Harris TJ, Albesiano E, Pradilla G, Ford E, Wong J, Hammers HJ, Mathios D, Tyler B, Brem H, Tran PT, Pardoll D, Drake CG, Lim M. Anti-PD-1 blockade and stereotactic radiation produce long-term survival in mice with intracranial gliomas. Int J Radiat Oncol Biol Phys 2013;86:343-9.

96. Filley AC, Henriquez M, Dey M. Recurrent glioma clinical trial, CheckMate-143: the game is not over yet. Oncotarget 2017;8:91779-94.

97. Carter T, Shaw H, Cohn-Brown D, Chester K, Mulholland P. Ipilimumab and bevacizumab in glioblastoma. Clin Oncol (R Coll Radiol) 2016;28:622-6.

98. Preusser M, Lim M, Hafler DA, Reardon DA, Sampson JH. Prospects of immune checkpoint modulators in the treatment of glioblastoma. Nat Rev Neurol 2015;11:504-14.

99. Kim HJ, Evoli A. Immune checkpoint inhibitor therapy: a double-edged sword? Neurology 2017;89:1101-2.

100. Gelao L, Criscitiello C, Esposito A, Goldhirsch A, Curigliano G. Immune checkpoint blockade in cancer treatment: a double-edged sword cross-targeting the host as an "innocent bystander". Toxins (Basel) 2014;6:914-33. 